\title{
Development of Research-Based Modules in Educational Psychology Lectures to Improve Creativity
}

\author{
Wahidah Fitriani ${ }^{1}{ }^{凶}$, Elis Komalasari ${ }^{2}$, Mitsalina Adzhani ${ }^{3}$, Yuliana Nelisma ${ }^{4}$ \\ Psikologi Islam, Institut Agama Islam Negeri Batusangkar, Indonesia(1) \\ Pendidikan Islam Anak Usia Dini, Institut Agama Islam Negeri Batusangkar, Indonesia(2) \\ English Education, Institut Agama Islam Negeri Batusangkar, Indonesia( ${ }^{(3)}$ \\ Bimbingan dan Konseling Pendidikan Islam, Institut Agama Islam Negeri Batusangkar, \\ Indonesia( ${ }^{(4)}$ \\ DOI: $10.31004 /$ obsesi.v6i4.2314
}

\begin{abstract}
Abstrak
Mahasiswa harus memiliki kreativitas yang tinggi agar dapat memenuhi kebutuhan dunia kerja. Kenyataannya, kreativitas mahasiswa masih rendah dan belum ada produk berupa modul berbasis riset yang dapat meningkatkan kreativitas mahasiswa. Penelitian ini bertujuan untuk mengetahui bagaimana perancangan modul berbasis riset pada mata kuliah psikologi pendidikan untuk meningkatkan kreativitas mahasiswa IAIN Batusangkar yang memenuhi kriteria valid, praktis dan efektif. Penelitian ini menggunakan jenis penelitian dan pengembangan. Subyek penelitian adalah 30 orang mahasiswa Jurusan PIAUD semester II yang sedang mengambil mata kuliah psikologi pendidikan. Proses pengembangan dilakukan dalam empat tahap, yaitu pendefinisian, perancangan, pengembangan dan diseminasi. Proses validasi dilakukan oleh 2 orang pakar materi psikologi pendidikan anak usia dini dan 1 orang ahli media. Analisis data yang digunakan dalam penelitian ini adalah analisis kualitatif dan kuantitatif. Hasil penelitian menunjukkan bahwa modul psikologi pendidikan berbasis riset telah memenuhi kriteria valid, praktis dan efektif untuk meningkatkan kreativitas kognitif maupun nonkognitif.
\end{abstract}

Kata Kunci: modul berbasis riset; psikologi pendidikan; kreativitas.

\begin{abstract}
Students must have high creativity to meet the needs of the world of work. However, Student creativity is still low, and there is no product in the form of a research-based module that can improve student creativity. This study aims to determine how to design research-based modules in educational psychology courses that meet valid, practical, and effective criteria to improve the creativity of students. This research uses research and development type. The research subjects were 30 students of the PIAUD semester II who took educational psychology courses. The development process is carried out in four stages: definition, design, development, and dissemination - two experts on educational pychology of early childhood materials and one media expert carried out the validation process. The data analysis used is qualitative and quantitative analysis. The results showed that the research-based educational psychology module had met the valid, practical, and effective to improve aptitude and nonaptitude creativity.
\end{abstract}

Keywords: Research-based module; educational psychology; creativity.

Copyright (c) 2021 Wahidah Fitriani, et al.

$\triangle$ Corresponding author :

Email Address: wahidahfitriani@iainbatusangkar.ac.id

Received 19 December 2021, Accepted 4 February 2022, Published 14 February 2022 


\section{INTRODUCTION}

Society 5.0 is an attempt to overcome various social problems faced by humans. The slogan of society 5.0 was issued by the Japanese state. According to the Japanese government, to overcome these various problems, they can be solved by integrating various technologies that are the results of innovations in the era of the industrial revolution 4.0 (Fitriani, 2020). Society 5.0 is like two sides of a coin, having both positive and negative impacts. Positively, society 5.0 will simplify human life because it utilizes technology to help humans in various lifelines. Meanwhile, on the other hand, the era of society 5.0 can degrade the labor market. The World Economic Forum predicts that by 2022, as many as $54 \%$ of employees will need retraining due to new types of jobs that continue to emerge and more positions being reduced because they will be replaced by machines (WEF, 2018).

Reducing the types of work due to the direct use of technology will impact the number of workers. As in Indonesia, for example, data from the Central Statistics Agency noted that in February 2019, as many as 6.82 million people were unemployed (BPS, 2018). Interestingly, from the BPS data, as many as $6.24 \%$ or as many as $42,556,800$ people from the total unemployed in Indonesia are those who have a bachelor's degree. This data is certainly worrying, considering that Indonesia has just entered the era of the industrial revolution 4.0, the unemployment rate is still high. Imagine, if society 5.0 were present in Indonesia, of course, the unemployment rate would improve. Logically, those who already have a bachelor's degree are still unemployed, especially those who have graduated from a lower level of education (Sumarno, 2019).

This research is present as a form of anxiety if the younger generation, especially students of State Institute for Islamic Studies Batusangkar, cannot develop the skills needed to face the era of society 5.0. The fact that a sophisticated future life is accompanied by the latest technological devices to facilitate human life is in sight (Kurniawan \& Aiman, 2020). If students do not immediately arm themselves with the relevant skills, their role may be degraded by increasingly intelligent machines. Finally, after becoming a scholar, they only become unemployed or game addicts who ruin their future (Sudarmanto et al., 2021). Coupled with the Covid-19 pandemic, many jobs have been reduced, some have even been lost, opportunities and job vacancies have become increasingly tricky and fewer (Zwagery, 2020). If students do not have creativity in thinking and acting, they will be eroded by the times and become unemployed.

Currently, university graduates also contribute to unemployment, a burden on the state. The relevance of university graduates to the need for labor is essential in efforts to prevent unemployed graduates (Ngah et al., 2019). At State Institute for Islamic Studies (IAIN) Batusangkar, in particular, the Faculty of Education and Teacher Training has a goal: to produce graduates who are competent, critical, innovative, and competitive in the world of work. For Faculty of Education and Teacher Training students to have competitiveness in work, sufficient provisions are needed. Among them is by providing a learning curriculum relevant to the needs of the world of work. The curriculum aims to develop students' potential and then equip them with various competencies and skills that support future success. One of the skills in question contains aspects of creativity.

According to Munandar, creativity is an individual's ability to make new combinations based on existing data, information, or elements (Prastiyaningtyas, 2019, Wati, A. et al, 2020). Furthermore, Munandar gives the characteristics of individuals who have creativity: imaginative, have the initiative or initiative, have broad interests, are not rigid or inhibited in thinking, have high curiosity, love adventure, dare to try and take risks or not. Afraid to fail because of making mistakes, dare to have opinions, and have strong beliefs (Syaputra, 2021). Creativity in society 5.0 plays a significant role so that humans continue to innovate to find things that can make life easier. 
The ability of creativity has been embedded in humans because it is in the form of potential bestowed and carried from birth. However, some humans can develop some who are not in its development. Therefore, the provision and development of creativity is a necessity that is a shared responsibility. Starting from the government, the community, especially educational institutions. This is under the mandate contained in Law no. 20 of 2003 concerning the national education system; Article 3 states that the function of national education is to develop capabilities, shape the character and civilization of a dignified nation and educate the nation's life.

Based on the phenomena encountered and experienced by researchers as lecturers in educational psychology courses from 2016 to 2019, the facts obtained are that: 1) Students tend to get references very quickly from various sources in cyberspace but do not try hard to understand its contents. 2) Students do not attempt to change the content of papers obtained in cyberspace and edit them carelessly. 3) Students tend to master theory but cannot relate to it, let alone apply it in the real world. 4) Even though the lecturer has been assigned to make interesting power points and videos related to the material to be delivered, students make them in a makeshift manner. They do not show innovative work. Some of the facts above show that students still have low aptitude and non aptitude creativity.

The above facts are also supported by research conducted by (Alfiani Athma Putri Rosyadi, 2018), which shows that students still experience weaknesses in creativity, especially those related to flexibility and originality. This indicates that teaching materials are needed to support the teaching and learning process to improve student creativity. One of the teaching materials that can overcome the problem of low student creativity is a research-based module (Fitriyati et al., 2015). The development of research-based modules can be an alternative that can be proposed to improve student creativity. This can be seen from the primary purpose of doing research-based modules to facilitate students in expressing their ideas (Mustakim et al., 2020). In addition, research-based modules can also make students link theory with existing practices in everyday life so that meaningful learning occurs. Furthermore, the e-module was successfully developed through the stages of analysis, design, development, implementation and evaluation. The results of the average percentage of total teacher responses are $92.30 \%$, the results of the average percentage of total student responses are $94.46 \%$ with the criteria of "Very Practical" and it can be concluded that the web-based Indonesian e-Module is suitable for use as Bahasa Indonesia teaching materials in class XI SMK (Oktavia, 2021).

Based on the background of the problem above, the researcher proposes the research title "Development Of Research-Based Module In Educational Psychology Courses To Improve Creativity Of Piaud Students Of Iain Batusangkar." The research-based modules referred to in this study are independent teaching materials for students, which contain a combination of theory and research activities, so that students can understand concretely the application of the concepts learned. The use of research-based modules also can help the student to achieve competency in educational psychology courses, especially in a daily life applications (Fitriani et al., 2021).

This is an effort to create reliable generations in the future who can balance intellectual abilities with technological adaptation. Moreover, this research targets students majoring in Early Childhood Islamic Education (PIAUD), making this research even more critical because prospective teachers in Early Childhood Education (PAUD) are expected to have high creativity. This is in accordance with Permendiknas No. 16 of 2007 which requires an early childhood teacher to have professional competence, in which the teacher must be able to creatively process material in the field of development according to the level of development of students (Permendiknas No. 16 Tahun, 2007). With the creativity possessed by these prospective PAUD teachers, they will be able to carry out their profession as PAUD teachers in the future with full of innovation and new ideas, so that early childhood children who are still in the golden period of life development can also be stimulated by all their potential and talents. Creative from an early age. 
Given that PAUD teachers are laying the initial foundation for early childhood education, it is very urgent to prepare prospective PAUD teachers well to become creative and innovative PAUD teachers in the future. The problem in this research is how to design research-based modules in educational psychology courses to improve the creativity of State Institute for Islamic Studies Batusangkar students who meet the valid, practical, and effective criteria? Meanwhile, the purpose of this research is to find out how to design research-based modules in educational psychology courses to improve the creativity of State Institute for Islamic Studies Batusangkar students who meet the valid, practical, and effective criteria.

\section{METHODS}

This research is classified in the type of development research better known as research and development (Silalahi, 2018). In this case, a research-based module was developed in the educational psychology course to improve students' creativity in the Department of Early Childhood Islamic Education. The development procedure used in the research (Wahyuni et al., 2018) is the Thiagarajan model or 4-D Model consisting of four stages, namely the definition stage, the design stage, the development stage, and the dissemination stage. It is limited to stage 3. Data collection is carried out through the validation process of this research-based module. The target of this development is students of the Department of Early Childhood Islamic Education (PIAUD) Faculty of Tarbiyah and Teacher Training State Institute for Islamic Studies Batusangkar semester 2, with 30 students.

Furthermore, this study used data collection methods in the form of interviews. This method is used when researchers conduct a needs analysis by asking educational psychology lecturers regarding student creativity and the availability of media that have been used in educational psychology lectures. In addition, interviews were also conducted when researchers conducted product trials to see and find out the practicality of the media developed to obtain data on the weaknesses and strengths of the product. After the data is received, a revision or improvement of the product is carried out.

This study also uses a questionnaire or questionnaire. Researchers use this method to obtain data in the form of testing the validity or feasibility of research-based modules in terms of material and the feasibility of the modules used by lecturers so that they can achieve the goals of developing this product.

The data analysis techniques used in this study are qualitative analysis techniques and quantitative analysis. For data analysis in general, descriptive analysis was used. For quantitative data, the researcher uses descriptive statistical analysis. The observations, interviews, lecturer suggestions, validation, and documentation notes were analyzed qualitatively. Researchers can describe the research results in detail with this qualitative data analysis. Some tips will be used for product improvement at the revision stage. While the documentation notes are described to determine the effectiveness of the products developed when used by lecturers. Where this study is related to the response when using the researchbased module.

Researchers used validation sheets. This sheet is used to obtain data on the level of validity of the research-based modules developed as valid or not. This validation sheet was given to 3 experts. The 2 lecturers who are experts in educational psychology, namely Dani Yoselisa, M. Psi, Psychologist., and Zubaidah, M.Pd., Kons. Then, 1 lecturer who is a media expert, namely Dianti Yunia Sari, SE., M.Pd.

The research-based module validation sheet contains aspects that have been formulated. Each element is developed into several statements. The filling in the validation sheet is analyzed using a Likert scale with a range of up to 4 . Each account has an answer choice of 0 to 4 . Three lecturers fill out the module validation sheet at State Institute for Islamic Studies Batusangkar. The components observed can be seen in Table 1. 
Table 1. Aspects of Research-based Module Validation

\begin{tabular}{clcc}
\hline No & Aspect & Method of collecting data & Instrument \\
\hline 1 & Construct & Discussion with material experts & Sheet \\
2 & Content & Discussion with media experts & Validation \\
3 & Language & & \\
\hline
\end{tabular}

Quantitative analysis is used to describe the quality of the module based on the lecturer's assessment. Quantitative techniques are carried out by providing criteria adopted from (Azwar, 2012). The researcher carried out two stages of analysis, namely determining the average value obtained and making the criteria into four bars, namely, very good, good, sufficient, and less. The validation results from the validator on all assessed aspects are presented in tabular form (table 2).

Table 2. Validity Sheet Rating Scale

\begin{tabular}{ccc}
\hline Letter & Value Scale & Description \\
\hline A & 4 & Very good \\
B & 3 & Good \\
C & 2 & Enough \\
D & 1 & Not enough \\
\hline
\end{tabular}

In addition, the percentage of each validation sheet is searched using a modified technique (Purwanto, 2017) by using the following formula:

$$
\mathrm{NP}=\frac{\mathrm{R}}{\mathrm{SM}} \times 100 \%
$$

Description :

$\mathrm{NP}$ : the percentage value sought/expected

$\mathrm{R} \quad$ : Raw scores obtained

$\mathrm{SM} \quad$ : Ideal maximum score

100 : Fixed number

The results obtained are interpreted using the table 3.

Table 3. Validity Category of Validation Sheet

\begin{tabular}{cc}
\hline Range Persentase $(\%)$ & Criteria \\
\hline $81-100$ & Very Valid \\
$61-80$ & Valid \\
$41-60$ & Quite Valid \\
$21-40$ & Less Valid \\
$0-20$ & Invalid \\
\hline
\end{tabular}

Associated with data analysis to test the practicality. After trying the research-based module, the researcher asked the lecturers to fill out a questionnaire. The filling of this questionnaire was then analyzed using the formula modified by (Purwanto, 2017) as follows:

$$
\mathrm{NP}=\frac{\mathrm{R}}{\mathrm{SM}} \times 100 \%
$$

Description :

NP : the percentage value sought/ expected

$\mathrm{R} \quad$ : Raw scores obtained

SM : Ideal maximum score

100 : Fixed number 
Table 4. Lecturer Response Questionnaire Rating Scale

\begin{tabular}{ccc}
\hline Alternative Level of Practicality & Value & Description \\
\hline A & 4 & Agree \\
B & 3 & Agree \\
C & 2 & Just Agree \\
D & 1 & Disagree \\
\hline
\end{tabular}

Data from observations of the implementation of lecturer response questionnaires were analyzed using quantitative descriptive statistics with the table 5.

Table 5. Practicality Categories of Lecturer Response Questionnaire Assessment

\begin{tabular}{cc}
\hline Range Persentase $(\%)$ & Criteria \\
\hline $81-100$ & Very practical \\
$61-80$ & Practical \\
$41-60$ & Practical enough \\
$21-40$ & Less practical \\
$0-20$ & Not practical \\
\hline
\end{tabular}

Furthermore, for data analysis related to the effectiveness of the module. The researcher asked students to answer questions on the creativity level inventory by choosing one alternative answer with a tick $(\boldsymbol{V})$. Scoring is done by adding up student answers on each item. The higher the number of scores obtained, the higher the level of creativity. Next, the researchers compiled data tabulations and calculated each student's total number of scores and the number of item scores using Microsoft Office Excel 2010. The next step was to analyze the data statistically with a t-test using the IBM SPSS Statistics Version 20 (Ihwana et al., 2017). For more details, the research design can be seen in figure 1.

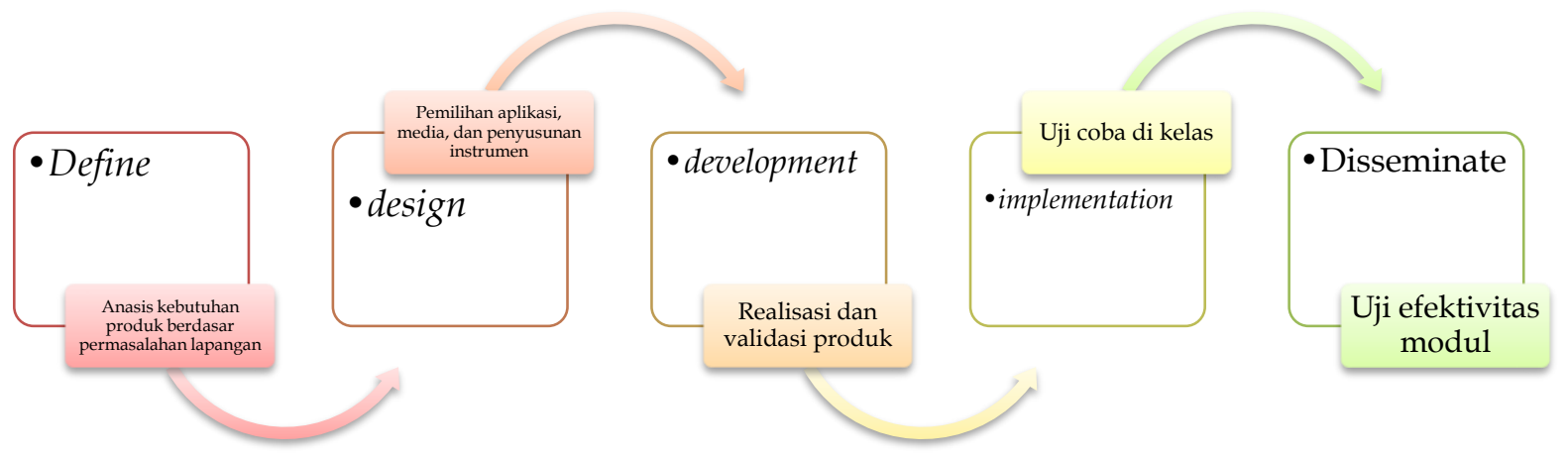

Figure 1. Stages of Adapted Product Development from the 4D Model

\section{RESULT AND DISCUSSION}

The module is designed to meet the needs of research-based learning in the Educational Psychology course by the educational psychology course syllabus. The results of the development are described in more detail as follows.

\section{Define}

The research team analyzed student characteristics, needs analysis, and indicator analysis at this stage. Data were collected through interview and survey techniques to lecturers in educational psychology courses and PAUD teachers as practitioners. 


\section{Analysis of Student Characteristics}

Student analysis was carried out to see the characteristics of students, including students, needs students' creative thinking abilities by knowing and understanding the features to design research-based modules with these elements. The trial subjects were secondsemester students in the Department of Early Childhood Islamic Education in this study. To study the characteristics of students, observations were made during lectures.

The observations showed that both the aptitude and nonaptitude creativity of students was not explored during lectures. The lecturers have not used appropriate strategies or teaching materials to improve creativity. Another found during lessons was that some children tended to be passive. This is because the lecturer uses the presentation and discussion method to feel bored. Students have different abilities to absorb, process, and store information. During the learning process, students are more likely to wait for an explanation from the lecturer.

This development research is based on the problem of the lack of student creativity in the lecture process; this is evidenced by the results of interviews with three lecturers with the following description:

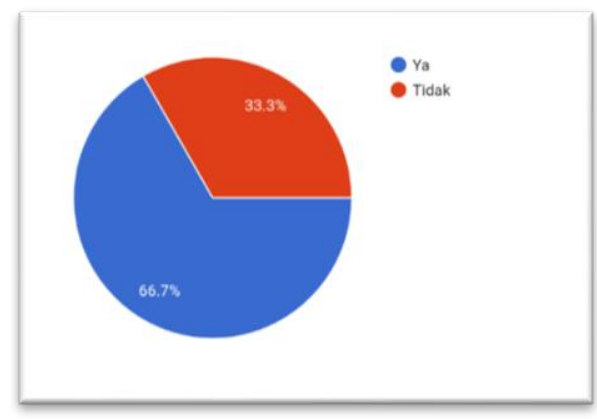

\section{Diagram 1. The Level of Student Creativity in Lectures}

The diagram above shows that $66.7 \%$ of students have demonstrated creativity in the lecture process while the remaining $33.3 \%$ are not creative. This implies that not all students have creative abilities. Creativity is essential as the respondents said that creativity is necessary and needed by students to interpret the material obtained in lectures to apply it when in the field of work. (Fakhriyani, 2016).

\section{Needs Analysis of the Module}

Interviews related to problems in lectures and the use of teaching materials used by lecturers of educational psychology courses, questions posed to lecturers are unstructured, questions are asked according to the answers given by lecturers, this aims to obtain information related to the level of need for the modules used. Developed. The interviews were conducted on three lecturers who teach Educational Psychology courses in different majors.

Based on the interviews, information was obtained that in the lecture process, teaching materials used by lecturers were still limited to source books and references from online media, and there were no modules to improve student creativity in educational psychology courses. When asked further about what media the respondents used in teaching educational psychology courses, in general, the respondents used PowerPoint media and journals for teaching materials, as for the presentation of the use of media at Diagram 2.

The diagram above shows that lecturers have not used lecture modules; in general, lecturers use theory books, journals, papers, and powerpoints. All respondents said they needed the development of modules in educational psychology courses; it was mentioned that the module could guide lectures more optimally and for uniformity. 
Developing research-based modules is an alternative for students because researchbased modules can improve students' creative thinking at the Department of Early Childhood Islamic Education. Information about the characteristics of students who are the object of using research-based modules and as a material for consideration in developing modules to improve creativity. Generally, students can study independently, and in groups, students need media or strategies to practice creative thinking skills. Knowing the characteristics of these students will make it easier to do research-based modules

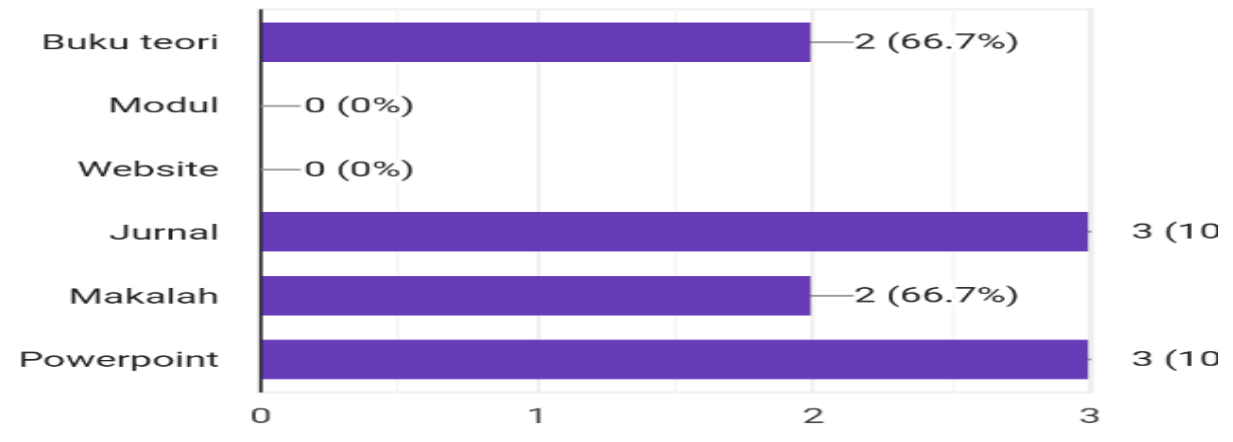

\section{Diagram 2. Media used when teaching Educational Psychology courses}

\section{Indicator Analysis}

After analyzing the needs of the lecturers for the module and analyzing the characteristics of students by surveying the level of student creativity, the next researcher conducted an indicator analysis of the material presented in the educational psychology course. Indicator analysis is carried out in two ways, namely: 1) Material analysis in the semester program design (RPS), 2) Analysis of material needs related to problems in the field for practitioners

Material analysis in the semester program design is carried out to evaluate the various materials contained in the RPS and reviewed based on field needs and problems teachers often encounter. To conduct material analysis, the researchers conducted interviews with practitioners in the field regarding what problems teachers often face in understanding student characteristics and classroom management and what materials are needed by teachers related to understanding student characteristics. In this case, the researcher interviewed 12 teachers from various PAUD institutions. The problems expressed by the teacher related to understanding student characteristics are 1) There is difficulty in understanding the characteristics of different children, 2) There are teacher difficulties in dealing with quiet and hyperactive children, 3) Teachers often experience problems with children's social development and 4) Teachers have difficulty coping with children from different sociocultural backgrounds

In addition to the problems frequently encountered by teachers in the field, the teachers said that what they had learned in college was sufficient to equip them to overcome student problems. However, some said that the material was still lacking to prepare students as prospective educators. The materials suggested by the teachers include:1) Creative competence in educating, 2) Manage classes and procedures for speaking and behaving politely with children, 3) The teacher's strategy in overcoming children's problems AND 4) Children's character building

From the interviews with teachers, the research team reviewed the RPS and considered input from teachers regarding necessary lecture materials to be given to students.

\section{Task Analysis}

The task analysis step improves student creativity by using assignments in researchbased modules. The tasks given are problem-solving and cooperative, which provide 
opportunities for students to seek information, formulate hypotheses, collect data, analyze data and draw conclusions from the data that has been compiled.

\section{Design}

The next stage is the design stage. At this stage, a research-based module is designed in the Educational Psychology course to improve student creativity. This research-based prototype module contains lecture material for one semester. Educational psychology course material is analyzed based on the needs stated in the semester program design. Meanwhile, the material determined and contained in the module is as follows: a) Introduction to educational psychology, which includes understanding, history, and research in educational psychology. b) Individual development, development process, and its influence on learning. c) Information Processing Theory. d) Learning style theory. e). learning theory. f). Motivation to learn. g) Creativity, interest, and talent. h). Class management. i). Measurement in education.

The above materials are contained in a research-based module and presented in 14 meetings to determine each competency that must be achieved by students in the Department of Early Childhood Islamic Education.

\section{Making Flowchart}

A flowchart is a flow chart for module creation, starting from module design, content design, and layout.

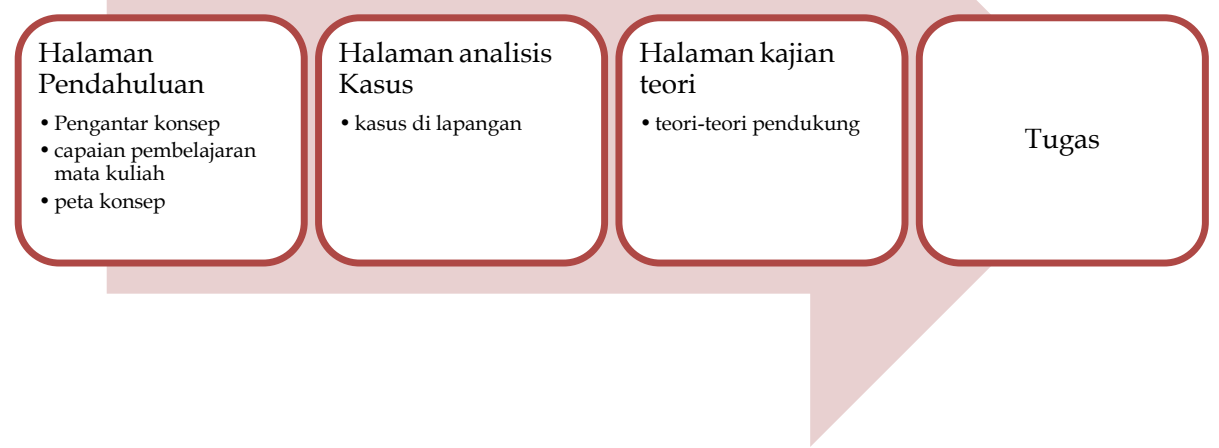

Figure 2. Flowchart of module creation

\section{They are making layouts.}

The next step is to create a layout. The layout is a series of material lecture layouts made as a whole to contain material, case examples, and assignments.

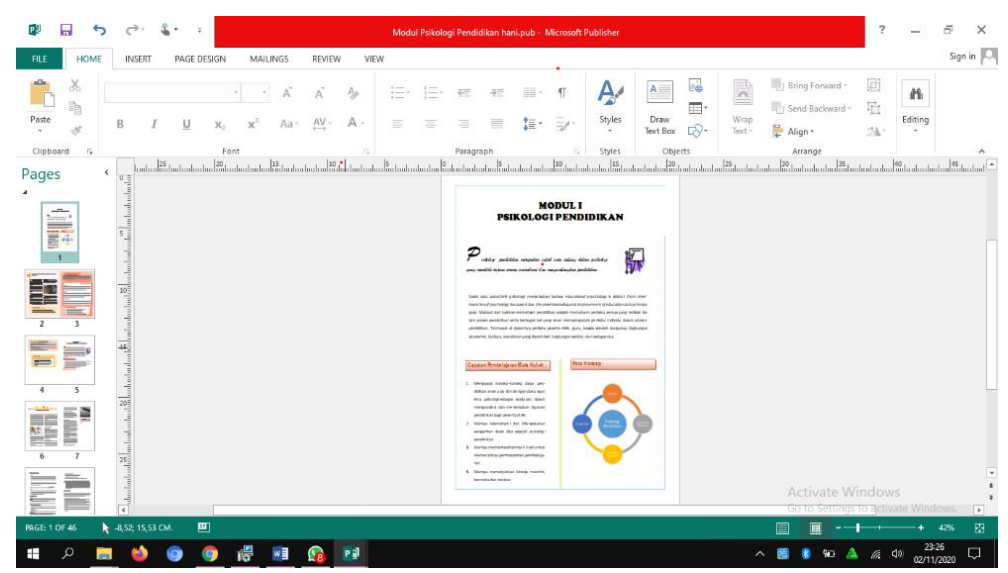

Figure 3. Module layout design 


\section{Gathering the required materials}

The materials used to develop research-based modules in creativity are various theories in educational psychology courses. As for the material, the research results were obtained from research journals and task analysis that supports students to develop creativity.

\section{Script setting}

Setting the script is assembling all existing materials following the demands of the manuscript.

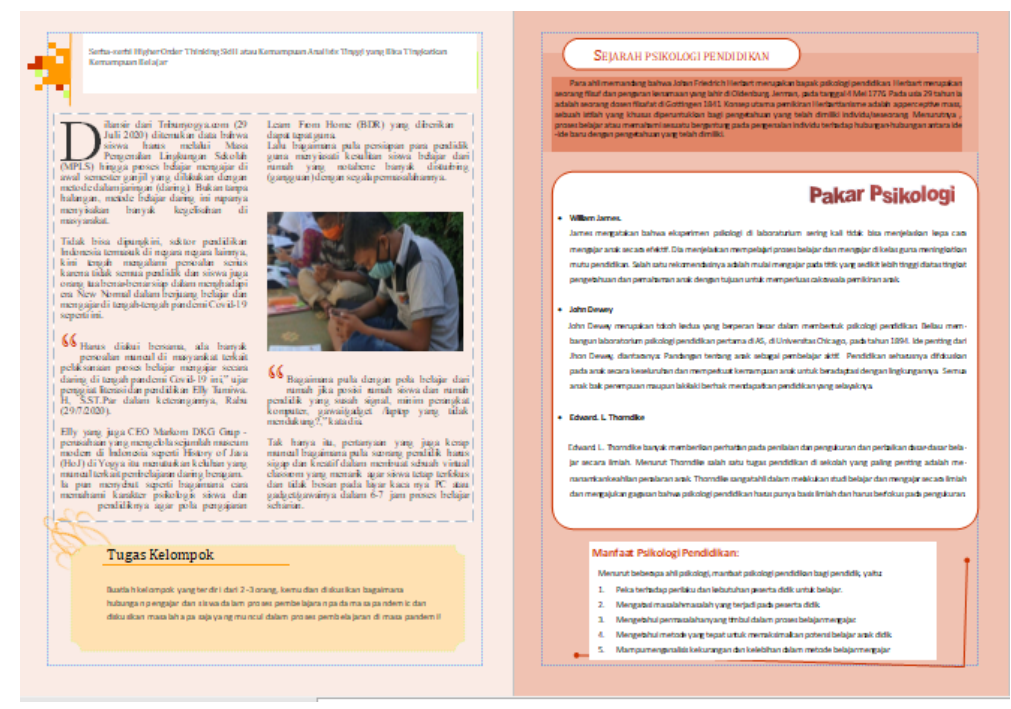

Figure 4. Assembling the materials according to the script

\section{Finishing}

The last stage is finishing, where this stage is the final process in doing research-based modules. If this stage is complete, researchers can use and apply the module to students.

\section{Development}

Based on the results of media expert validation, a score of $77 \%$ was obtained. The results show that the educational psychology module is in the correct category. Meanwhile, based on assessing the effects of material expert validation, a score of $82 \%$ was obtained. This shows that the research-based module developed is in an outstanding category. Regarding the practicality test for students, the results obtained were $85.29 \%$. This indicates that the research-based educational psychology module is in the convenient category. At the same time, the results of the practicality test for lecturers obtained a value of $76.47 \%$. This value indicates that the research-based educational psychology module is in the practical category, as for the input from the lecturer in the development of the module, namely so that the illustration of the image is more Islamic, the inclusion of pages on the module and the table of contents. The research team has accommodated this suggestion by improving the illustrations, runners, and table of contents.

Related to the module effectiveness test assessment, the researchers measured the level of student creativity through a creativity scale. Before using the module, students are asked to fill out a creativity scale to obtain the pre-test-test score. After that, the module is used in lectures according to the lecture schedule for one semester. After the study was completed according to the program, the researcher then asked the students to fill in the creativity scale again to obtain a post-test score. Furthermore, the researchers processed the data. The classification of the comparison of pre-test-test and post-test student creativity can be seen in the table 6 . 
Table 6. Classification Results in Comparison of Pretest and Posttest

\begin{tabular}{llllrlr}
\hline \multirow{2}{*}{ No. } & \multirow{2}{*}{ Score } & Categories & \multicolumn{2}{c}{ Press } & \multicolumn{2}{c}{ Posts } \\
\cline { 4 - 6 } & & & F & $\%$ & f & $\%$ \\
\hline 1. & $77-105$ & Height & & & 4 & $13 \%$ \\
2. & $49-76$ & Medium & 25 & $83 \%$ & 25 & $83 \%$ \\
3. & $21-48$ & Low & 5 & $17 \%$ & 1 & $4 \%$ \\
& Total & & 30 & $100 \%$ & 30 & $100 \%$ \\
\hline
\end{tabular}

Based on table 6, the overall pre-test-test and post-test results in the table above can be explained that in the pre-test-test results, there are 25 students in the medium category with a percentage of $83 \%$, and there are five students in the low class with a rate of $17 \%$. Meanwhile, in the post-test results, there were four students in the high category with a percentage of $13 \%$, 25 students in the medium class with a rate of $83 \%$, and one student in the low sort with a ratio of $4 \%$. From the data, the condition of the respondents in each category varies; there are high and medium and low.

This study supports the observations from previous studies, which show that student creativity is still not explored during lectures. This is because lecturers have not used appropriate strategies or teaching materials to improve creativity (Rahayu et al., 2020). Another found during classes was that some children tended to be passive (izzaty R E, 2017). This is because the lecturer uses the presentation and discussion method to feel bored. Students have different abilities to absorb, process, and store information. Students are more likely to wait for an explanation from the lecturer; the lecturer should provide training to students, as was done by (Herminayu \& Sulasmono, 2020). The training that has been carried out has not been practical because it does not use the training module. Expert validation resulted in a BCCT learning model training module with an outstanding category. At the limited trial stage, it showed a difference in the effect of using the module, further enhancing the competence of the trainees compared to training without using the module, which was calculated from the participants' pre-test-test and post-test scores.

The development of research-based modules is an alternative for students because research-based modules can improve students' creative thinking in the Department of Early Childhood Islamic Education (Prafitasari \& Sulistyarsi, 2020). Information about the characteristics of students who are the object of using research-based modules and as a material for consideration in developing modules to improve creativity. Generally, students can study independently, and in groups, students need media or strategies to practice creative thinking skills.

Speculation testing was carried out on the side effects of the post-test on the student creativity scale. This speculation test is carried out using parametric tests because the data are scattered and homogeneous (Soedrajat et al., 2021). In this study, the authors used the T-test. The T-test was used to answer the problem formulation 'How to design research-based modules in educational psychology courses to improve the creativity of State Institute for Islamic Studies Batusangkar students who meet the effective criteria?'. If the value of Asymp.Sig. (2-tailed) is less than $<0.05$, then Ha is accepted. If the value of Asymp.Sig. (2tailed) is more significant than $>0.05$, then Ha is rejected.

Based on the results of data analysis using paired sample t-test data analysis techniques, it is found that the correlation value between pre-test-test and post-test has a solid and positive relationship; it can be seen from the results of the calculation of paired sample t-test analysis on table 7. From the results of table 7 above, there is a value to (9.181)> tt (1.699) at a $0.05 \mathrm{df} 29$. This means that Ha is accepted and Ho is rejected. This means that the use of research-based modules in educational psychology courses effectively improves the creativity of State Institute for Islamic Studies Batusangkar students. This study strengthens the research results of (Rosyadi 2018), who found that research-based modules improve student creativity. The results 
of this study to enhance also the results of research conducted by (Fitriyati et al., 2015), who produced a teaching material product module in the form of a research-based module that contains techniques and research results of antiproliferative testing of $\mathrm{ZnO}$ particles and $\mathrm{UV}$ irradiation on MCF-7 cancer cells in vitro. For the subject of Biotechnology.

Table 7. $\mathrm{T}$. test results

\begin{tabular}{|c|c|c|c|c|c|c|c|c|c|}
\hline \multicolumn{10}{|c|}{ Paired Samples Test } \\
\hline & & \multicolumn{5}{|c|}{ Paired Differences } & \multirow[b]{3}{*}{$\mathrm{T}$} & \multirow[b]{3}{*}{ Df } & \multirow{3}{*}{$\begin{array}{l}\text { Sig. (2- } \\
\text { tailed) }\end{array}$} \\
\hline & & \multirow[b]{2}{*}{ Mean } & \multirow{2}{*}{$\begin{array}{c}\text { Std. } \\
\text { Deviation }\end{array}$} & \multirow{2}{*}{$\begin{array}{l}\text { Std. } \\
\text { Error } \\
\text { Mean }\end{array}$} & \multicolumn{2}{|c|}{$\begin{array}{l}95 \% \text { Confidence } \\
\text { Interval of the } \\
\text { Difference }\end{array}$} & & & \\
\hline & & & & & Lower & Upper & & & \\
\hline $\begin{array}{l}\text { Pair } \\
1\end{array}$ & $\begin{array}{l}\text { Pre Tes } \\
\text { - Post } \\
\text { Tes }\end{array}$ & 10,26667 & 6,12476 & 1,11822 & 7,97964 & 12,55369 & 9,181 & 29 & , 000 \\
\hline
\end{tabular}

\section{CONCLUSION}

The module's design has followed the stages in development research which is carried out through needs analysis, analysis of student characteristics, analysis of indicators, and analysis of tasks that can improve student creativity. The module design goes through a preparation process, starting from determining instructional objectives, determining studies based on semester lecture designs (RPS), and determining assignments to stimulate student creativity. The module development has gone through validation testing, practicality testing, and effectiveness testing. Based on the research stages, the results obtained that the researchbased modules in the educational psychology course developed have met the valid, practical, and effective criteria.

\section{ACKNOWLEDGMENTS}

The writing team would like to thank LPPM State Institute for Islamic Studies Batusangkar for funding this research. Also, to the experts who have validated the product of research-based modules in educational psychology courses, we thank you very much. Finally, we thank you for participating in this research to the students.

\section{REFERENCES}

BPS. (2018). Badan Pusat Statistik Provinsi Bali. Badan Pusat Statistik Bali.

Fakhriyani, D. V. (2016). Pengembangan Kreativitas Anak Usia Dini. Wacana Didaktika. https://doi.org/10.31102/wacanadidaktika.4.2.193-200

Fitriani, W. (2020). Preparing Young Generations ' Spiritual Intelligence To Face Society 5 . 0. 4th International Conference on Education, 1(3), 11-22.

Fitriani, W., Komalasari, E., \& Adzhani, M. (2021). Pengembangan Modul Berbasis Riset pada Mata Kuliah Psikologi Pendidikan untuk Meningkatkan Kreativitas Mahasiswa Menghadapi Society 5.0. Laporan Penelitian LPPM IAIN Batusangkar.

Fitriyati, U., Mufti, N., \& Lestari, U. (2015). Pengembangan Modul Berbasis Riset Pada Matakuliah Bioteknologi. Jurnal Pendidikan Sains.

Herminayu, H., \& Sulasmono, B. S. (2020). Pengembangan Modul Pelatihan Model Pembelajaran BCCT Bagi Guru dan Kepala Taman Kanak-Kanak. Jurnal Obsesi : Jurnal Pendidikan Anak Usia Dini. https:// doi.org/10.31004/obsesi.v4i2.512

Ihwana, F. M., Isharijadi, \& Wijaya, A. L. (2017). Pengaruh kompensasi dan motivasi kerja terhadap loyalitas perawat magang pada rumah sakit lanud iswahjudi maospati kab. magetan. Jurnal Ekonomi Dan Bisnis.

izzaty R E. (2017). Perilaku anak prasekolah, masalah dan cara menghadapinya. PT Elex Media Komputindo Jakarta. 
Kurniawan, N. A., \& Aiman, U. (2020). Paradigma Pendidikan Inklusi Era Society 5.0. JPD: Jurnal Pendidikan Dasar.

Mustakim, A., Jumini, S., \& Firdaus, F. (2020). Pengaruh Penggunaan Modul Pembelajaran Fisika Dengan Pendekatan Saintific Berbasis Riset Untuk Meningkatkan Literasi Sains Siswa Kelas Viii Di Smp Takhassus Al-Qur'an 2 Dero Duwur, Di Wonosobo Tahun Ajaran 2018/2019. Prosiding Seminar Nasional Pendidikan Fisika FITK UNSIQ. 2 .

Ngah, M. A., Halid, S., \& A Rosli, F. (2019). EKSKLUSIF: Graduan, siswazah miskin, B40 sukar dapat kerja setimpal. Berita Harian Online.

Oktavia, A. S. (2021). Pengembangan E-Modul Bahasa Indonesia Berbasis Web di SMK Negeri 2 Wajo. Jurnal Universitas Negeri Makasar.

Permendiknas No. 16 tahun, 16 tahun 2 Mendiknas 245 (2007). http:// digilib.unila.ac.id/11478/16/16. BAB II.pdf

Prafitasari, N. F., \& Sulistyarsi, A. (2020). Penyusunan Modul Bioteknologi Berbasis Riset. Prosiding Seminar Nasional ....

Prastiyaningtyas, A. A. (2019). Tingkat Kreativitas Mahasiswa Angkatan 2016 Program Studi Bimbingan dan Konseling Universitas Sanata Darma Yogyakarta [Sanata Darma]. http://repository.usd.ac.id/33204/2/151114007_full.pdf

Purwanto, E. A. (2017). Metode Penelitian Kuantitatif. Tajdidukasi: Jurnal Penelitian Dan Kajian. https://doi.org/10.47736/tajdidukasi.v9i1.16

Rahayu, H., Yetti, E., \& Supriyati, Y. (2020). Meningkatkan Kreativitas Anak Usia Dini melalui Pembelajaran Gerak dan Lagu. Jurnal Obsesi: Jurnal Pendidikan Anak Usia Dini. https://doi.org/10.31004/obsesi.v5i1.691

Rosyadi, A.A.P. (2018). Development of Research-Based Modules in Calculus Courses To. Math Didactic: Jurnal Pendidikan Matematika, 4(2), 128-135. https://doi.org/10.33654/math.v4i2.99

Rosyadi, Alfiani Athma Putri. (2018). Pengembangan modul berbasis riset pada mata kuliah kalkulus untuk meningkatkan kreativitas mahasiswa. Math Didactic: Jurnal Pendidikan Matematika. https://doi.org/10.33654/math.v4i2.99

Silalahi, A. (2018). Development Research (Penelitian Pengembangan) dan Research \& Development (Penelitian \& Pengembangan) Dalam Bidang Pendidikan/Pembelajaran. Research Gate.

Soedrajat, A., Ruslan, E., \& Sahel, S. (2021). Hubungan Usia Terhadap Presbiopi Pada Pengabdian Masyarakat di tengah Pandemi Covid-19 JABODETABEK. Prosiding Seminar Nasional Pengabdian Masyarakat Universitas Ma Chung. https:// doi.org/10.33479/senampengmas.2021.1.1.15-22

Sudarmanto, E., Mayratih, S., Kurniawan, A., Abdillah, L. A., Martriwati, M., Siregar, T., Noer, R. M., Kailani, A., Nanda, I., Nugroho, A. G., Sholihah, M., Rusli, M., Yudaningsih, N., \& Firmansyah, H. (2021). Model Pembelajaran Era Society 5.0. Penerbit Insania.

Sumarno. (2019). Pembelajaran kompetensi abad 21 menghadapi era Society 5.0. Prosiding SEMDIKJAR (Seminar Nasional Pendidikan Dan Pembelajaran).

Syaputra, J. (2021). Peran Mind Mapping Dalam Mengembangkan Kreativitas Mahasiswa Bahasa Indonesia Pada Mata Kuliah Morfologi di Muhammadiyah Manokwari. Jurnal Bindo Sastra, 5(1), 1-6. https://jurnal.um-palembang.ac.id/bisastra/article/view/2418

Wahyuni, H., Kiswardianta, R. B., Yuhanna, W. L., Biologi, P., \& Timur, J. (2018). Pengembangan modul berbasis riset pada mata kuliah anatomi tumbuhan. Prosiding Seminar Nasional.

Wati, A. Mariani, D., Wati E., Hasibuan, J.S. Fitriani, W. (2020). Peningkatan Kreativitas Anak TK Pada Masa Covid-19 Melalui Permainan Kolase Dengan Menggunakan Bahan Alam. Yaa Bunayya, 4(2), 99-107. https://doi.org/10.33061/jai.v4i1.3025

WEF. (2018). The Future of Jobs Report 2018. In Economic Development Quarterly.

Zwagery, R. V. (2020). Kecemasan menghadapi dunia kerja pada mahasiswa fresh graduate pada masa pandemi Covid 19. Prosiding Temu Ilmiah Nasional (TEMILNAS XII), Temilnas Xii, $10-14$. 